Int. J. Environ. Res. Public Health 2004, 1(2), 100-105

International Journal of

\title{
Mitogenic and Cytotoxic Effects of Pentachlorophenol to AML 12 Mouse Hepatocytes
}

\author{
Waneene C. Dorsey $^{1 *}$, Paul B. Tchounwou ${ }^{2}$ and Dwayne Sutton ${ }^{2}$ \\ ${ }^{1}$ Wildlife Biology Unit, Grambling State University, Grambling, LA 71245, USA. \\ ${ }^{2}$ Molecular Toxicology Research Laboratory, NIH - Center for Environmental Health, School of Science and Technology, \\ Jackson State University, 1400 Lynch Street, P.O. Box 18540, Jackson, Mississippi, USA. \\ *Correspondence to Dr. Waneene C. Dorsey. Email: dorseywc2002@yahoo.com
}

Received: 28 April 2004 / Accepted: 10 July 2004 / Published: 30 September 2004

\begin{abstract}
Pentachlorophenol (PCP), an organochlorine fungicide, is extensively used in the United States for the protection of wood products. Moreover, widespread agricultural, domestic, and industrial applications have caused PCP-contaminants to enter the food chain from the environment. There is accumulating evidence indicating that PCP is highly toxic to humans, and causes injury to major organs including the lung, liver, kidneys, heart, and brain. While PCP has been shown to induce systemic toxicity and carcinogenesis in several experimental studies, the literature is scarce regarding its toxic mechanisms of action. Recent investigations in our laboratory have shown that PCP exerts both cytotoxic and mitogenic effects in human liver carcinoma $\left(\mathrm{HepG}_{2}\right)$ cells [1], and in primary culture of catfish hepatocytes [2]. In the present study, we hypothesized that PCP exposure will trigger similar cytotoxic and mitogenic responses in AML 12 Mouse hepatocytes. To test this hypothesis, we performed the MTT assay for cell viability in PCP-treated and control cells. Data obtained from this experiment indicated a biphasic response with respect to PCP toxicity; showing a hormosis effect characterized by mitogenicity at lower levels of exposure, and cytotoxicity at higher doses. Upon $48 \mathrm{hrs}$ of exposure, PCP chemical doses required to cause $50 \%$ reduction in the viability $\left(\mathrm{LC}_{50}\right)$ of AML 12 mouse hepatocytes was computed to be $16.0 \pm 2.0 \mu \mathrm{g} / \mathrm{mL}$. These results indicate that, although the sensitivity to PCP toxicity varies from one cell line to another, its toxic mechanisms are similar across cell lines.
\end{abstract}

Key words: pentachlorophenol, cytotoxicity, mitogenicity, AML 12 mouse hepatocytes

\section{Introduction}

Chlorinated aromatic pesticides are pervasive environmental contaminants. They are well-known for their biocidal action against a broad spectrum of insects and microorganisms. The manufacturing of these compounds is usually achieved by direct chlorination of phenol or alkaline hydrolysis of synthetic chemicals [3]. A vast majority of chlorinated pesticides enter the environment via agricultural applications and wastewater effluents from chemical industries [4]. Exposure to this family of pesticides is a common and highly recognized cause of adverse health effects in humans and wildlife species. When released into the environment, these contaminants can interfere with the physiological performance of the endocrine, nervous, and reproductive systems [5] and influence sex differentiation in wildlife animals [6-8].

Pentachlorophenol (PCP) is a chlorinated aromatic fungicide that is commercially manufactured by direct chlorination of phenol with chlorine gas. It is a structurally halogenated hydrocarbon, composed of a benzene ring to which is attached a hydroxide radical making a chlorinated phenol. For more than 100 years, PCP has been the prevalent industrial wood preservative in the United States. Although creosote and chromated 
copper arsenate are popular wood preservatives, PCP has been used expansively in agricultural and domestic applications [9]. Agricultural applications include its use as an herbicide, algicide, defoliant, and fungicide [10]. Domestic applications of PCP can be found in veterinary supplies, disinfectants, fabrics, military uniforms, homecare and pharmaceutical products. In undeveloped parts of the world, PCP is used as a rot proofing agent to protect raw cotton or loom state fabric during transportation. As of 1977, an average of 50 million pounds of PCP was produced annually in the United States [11]. The widespread use of PCP has resulted in soil, water, and food contamination. At least 313 of 1,585 Superfund sites from the National Priorities List have been identified by United States Environmental Protection Agency (U.S. EPA) where PCP was found [12].

Exposure to $\mathrm{PCP}$ can result in the modulation of neurological responses; impairment to DNA that may lead to cancer; and hematological and immunological dysfunctions [13, 14]. Pulmonary absorption of vapors, aerosols, dusts, and absorption via the skin and gastrointestinal tract, represents relevant routes of lowlevel exposure to PCP. Respiratory manifestations such as congestion of lungs, irritation of respiratory tract, sneezing, coughing, shortness of breath are the symptoms of PCP inhalation [15].

Symptoms of abdominal pain, nausea, fever, and aggravation of the eye, skin, and throat are heavily linked to inhalation [16]. Moreover, high levels of PCP vapors have been associated with obstruction of the circulatory system, permanent visual impairment, and central nervous system damage [16]. Alternatively, dermal contact is the most dangerous route of exposure for humans, although, inhalation of PCP is considered to be a common route of exposure in the workplace. Hodgkin's disease, acute leukemia, and soft-tissue sarcoma have been associated with occupational exposure to technical-grade PCP [17].

Animal studies show toxicant insult to the cardiovascular, hepatic, immune, and central nervous systems from acute oral exposure to PCP [17]. Median lethal concentration and dose $\left(\mathrm{LC}_{50}\right.$ and $\left.\mathrm{LD}_{50}\right)$ tests in rats and mice have shown PCP to have high toxicity from inhalation exposure and extreme toxicity from oral exposure [17]. At high-level exposure, PCP has the potential to induce tumorigenic [18] and carcinogenic activity [19] in mice. Similarly, oncogenic activity in mice has been documented as infrequent liver tumors, adrenal medulla pheochromocytomas, and hemangiomas [20].

Intermittent delirium, rigors, flushing and excitement are common symptoms to both children and adults from acute exposure. Subsequently, PCP exposure can also cause neurological disorders of tachypnea, cerebral edema, and swelling of the myelin sheath [21]. Chronic exposure to PCP causes injury to the liver, kidneys, and central nervous system. Blood levels of children on the average are 1.8 times higher than adults; indicating that children are more susceptible to PCP exposure [21]. Babies that nurse liberally, experience tachycardia, hepatomegaly, progressive metabolic acidosis, proteinuria, azotemia, irritability followed by lethargy, pneumonia or bronchitis, and aplastic anemia [21]. Evidence of human mutagenicity and carcinogenesis due to PCP exposure is inadequate. However, the U.S. EPA has established PCP as a probable human carcinogenGroup $B_{2}$, based on suggestive evidence of carcinogenicity from laboratory animal studies [17].

It is believed that the mechanism by which PCP exerts its toxic action involves uncoupling mitochondrial oxidative phosphorylation, thereby causing accelerated aerobic metabolism and increasing heat production [22, 23]. Previous investigations in our laboratory have shown that PCP induces acute toxicity and transcriptionally activates a constellation of stress genes in $\mathrm{HepG}_{2}$ cells [24]. From our laboratory findings, we demonstrated that PCP has the ability to undergo Phase I biotransformation in the liver (CYP1A1 and XRE), to cause cell proliferation ( $c$-fos), to cause growth arrest and DNA damage (GADD153 and p53), to influence the toxicokinetics of metal ions (HMTIIA), and to induce proteotoxic effects (HSP70 and GRP78) in $\mathrm{HepG}_{2}$ cells $[1,24]$. Our laboratory has recently reported that PCP exerts both cytotoxic and mitogenic effects in human liver carcinoma $\left(\mathrm{HepG}_{2}\right)$ cells [1], and primary culture of catfish hepatocytes [2]. In the present study, we hypothesize that PCP exposure will trigger similar cytotoxic and mitogenic responses in AML 12 Mouse hepatocytes.

\section{Materials and Methods}

\section{Chemicals and Reagents}

Pentachlorophenol $\left(\mathrm{C}_{6} \mathrm{Cl}_{5} \mathrm{OH}\right.$, CAS No. 87-86-5, Lot No. 01530TS), with purity $98.0 \%$ was purchased from Sigma-Aldrich Chem Co., (St. Louis, Missouri). Dulbecco's Modified Eagle's Medium (DMEM) was purchased from Hyclone (Lot No. ANK19799; Logan, Utah) and tissue culture supplements were purchased from American Type Culture Collection (ATCC) Manassas, VA. Dulbecco's phosphate buffered saline (Lot No. 1163547) was obtained from Invitrogen Corporation (Grand Island, New York). Thiazolyl blue trazolium bromide CAS 298-93-1, purity 97.5\%, and dimethyl sulfoxide were purchased from Sigma-Aldrich (St. Louis, Missouri).

\section{Preparation and Culture of AML 12 Mouse Hepatocytes}

Alpha mouse liver 12 (AML 12) hepatocyte cultures have been established from a mouse transgenic for human transforming growth factor $\alpha$ (ATCC CRL-2254, Manassas, VA). The cells were stored in liquid nitrogen in the laboratory until use. Next, cells were thawed for 2 min in a dry bath at $37^{\circ} \mathrm{C}$. After thawing, the content of each vial was transferred to a $75 \mathrm{~cm}^{2}$ tissue culture flask 
diluted with DMEM, supplemented with $10 \%$ fetal bovine serum (FBS) and 1\% streptomycin and penicillin, and incubated at $37^{\circ} \mathrm{C}$ under an atmosphere of $5 \% \mathrm{CO}_{2}$ incubator in humidified air to allow the cells to grow and form a monolayer in the flask. Subsequently, cells grown to $80-95 \%$ confluence were washed with phosphate buffer saline (PBS), trypsinized with $5 \mathrm{~mL}$ of $0.25 \%(\mathrm{w} / \mathrm{v})$ EDTA, diluted, counted $\left(5 \times 10^{5}\right.$ cells/well), and seeded in 96-well microtiter tissue culture plates prior to treatment.

\section{Cell Viability Experiments for AML 12 Mouse Hepatocytes}

The MTT [3-(4,5-dimethylthiazol-2-yl)-2,5diphenyltetrazolium bromide] assay was performed for assessing cytotoxicity and cell proliferation activity in AML 12 mouse hepatocytes exposed to PCP. Viable cells are able to convert MTT to a water-insoluble formazan dye. AML 12 mouse hepatocytes were maintained in Dulbecco's Minimum Essential Medium (DMEM) supplemented with 10\% fetal bovine serum (FBS) and 1\% penicillin/streptomycin, and incubated at $37^{\circ} \mathrm{C}$ in a $5 \% \mathrm{CO}_{2}$ incubator. On day one, $180 \mu \mathrm{l} /$ well aliquots of cell solution $\left(5.0 \times 10^{5}\right.$ cells $\left./ \mathrm{mL}\right)$ were seeded in 96 well polystyrene tissue culture plates. On the day of exposure, old medium was removed and replaced with $180 \mu \mathrm{l}$ of fresh medium. Subsequently, $20 \mu \mathrm{l}$ aliquots containing varying concentrations of PCP were added to each well. Cells were placed in the incubator for $48 \mathrm{~h}$ at $37^{\circ} \mathrm{C}$ in $5 \% \mathrm{CO}_{2}$. One hour before the end of the incubation period, $20 \mu \mathrm{l}$ aliquots of MTT solution $(5 \mathrm{mg} / \mathrm{mL})$ were added to each well containing cells. Culture plates were incubated at $37^{\circ} \mathrm{C}$ for $1 \mathrm{~h}$. Medium containing MTT was removed and $200 \mu \mathrm{l}$ aliquots of DMSO were added to each well. The culture plates were placed in the $37^{\circ} \mathrm{C}$ incubator for $5 \mathrm{~min}$ to dissolve air bubbles, and transferred to a Bio-Tek Model - EL 800 microplate reader where absorbance was measured at $550 \mathrm{~nm}$.

\section{Statistical Analysis}

Absorbance readings of $550 \mathrm{~nm}$ from cell viability experiments were transferred to percentages to assess significant differences in treated cells compared to control cells. Graphs were made to illustrate the doseresponse relationship with respect to cytotoxicity or mitogenic activity. Standard deviations were determined, and the Student's t-test values were computed to determine if there were significant differences in cell viability in PCP-treated cells compared to control cells.

\section{Results}

\section{Cytotoxicity Assay}

We used the MTT-assay to assess the viability of PCP-treated AML 12 mouse hepatocytes. Mouse hepatocytes were exposed to increasing levels of PCP for $48 \mathrm{~h}$. Metabolically-active cells were able to convert MTT to water-insoluble dark-blue formazan crystals. The cytotoxic effect of PCP on AML 12 mouse hepatocytes is shown in Figure 1. A strong biphasicresponse pattern was demonstrated with respect to the cytotoxicity of PCP. Cell viability percentage values of PCP-treated hepatocytes were compared to the untreated control (100\% cell survival) to determine if there were any significant differences. The percentages for cell viability were recorded as $163 \pm 2.3 \%, 197 \pm 2.8 \%, 136$ $\pm 3.5 \%, 48 \pm 2.1 \%$, and $40 \pm 1.9 \%$ for concentrations of $1.95,3.95,7.815 .6$, and $31.2 \mu \mathrm{g} \mathrm{PCP} / \mathrm{mL}$, respectively. A statistically significant $(p<0.05)$ increase in cell viability within the concentration range of $0-7.8 \mu \mathrm{g}$ $\mathrm{PCP} / \mathrm{mL}$ was observed along with a concomitant decrease within the concentration range of 15.6 - $31.2 \mu \mathrm{g}$ $\mathrm{PCP} / \mathrm{mL}$. The $48 \mathrm{~h}-\mathrm{LC}_{50}$ was computed to be $16.0 \pm 2.0$ $\mu \mathrm{g} \mathrm{PCP} / \mathrm{mL}$, indicating that PCP is acutely toxic to $\overline{\mathrm{AML}}$ 12 mouse hepatocytes.

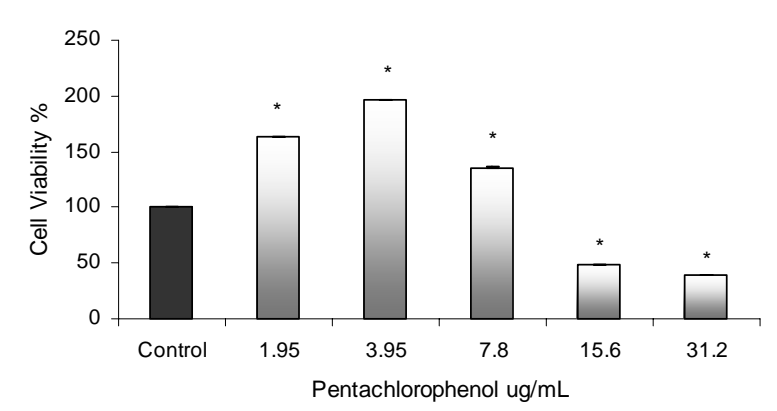

Figure 1. Toxicity of pentachlorophenol on AML 12 mouse hepatocytes. The cells were treated with serial dilutions $(0-31.2 \mu \mathrm{g} / \mathrm{mL})$ of PCP. Cell viability was measured by MTT assay as indicated in the methodology section. Absorbance readings taken from survival cells were converted to percentage cell viability. Bars are means \pm SDs, $n=3$ with 8 replications per concentration. *Significantly different $(p \leq 0.05)$ from control $(0 \mu \mathrm{g} / \mathrm{mL}$ PCP $)$.

\section{Mitogenic Activity in PCP-Treated AML 12 Mouse Hepatocytes}

To determine the mitogenic activity of PCP, we exposed mouse hepatocytes to sublethal concentrations of PCP $(0, .975,1.95,3.95$, and $7.8 \mu \mathrm{g} / \mathrm{mL})$. The mitogenic effect of PCP on AML 12 mouse hepatocytes is shown in Figure 2. Untreated hepatocytes were compared to PCP-treated hepatocytes to determine significant differences in stimulatory patterns. Data from this experiment exhibited a concentration and timedependent stimulatory effect on cell proliferation. All 24 $\mathrm{h}$ and $48 \mathrm{~h}$ test concentrations within the range of $.975-$ $7.80 \mu \mathrm{g} P C P / \mathrm{mL}$ induced a one-fold to three-fold increase in proliferative activity. For example, at $24 \mathrm{~h}$ of 


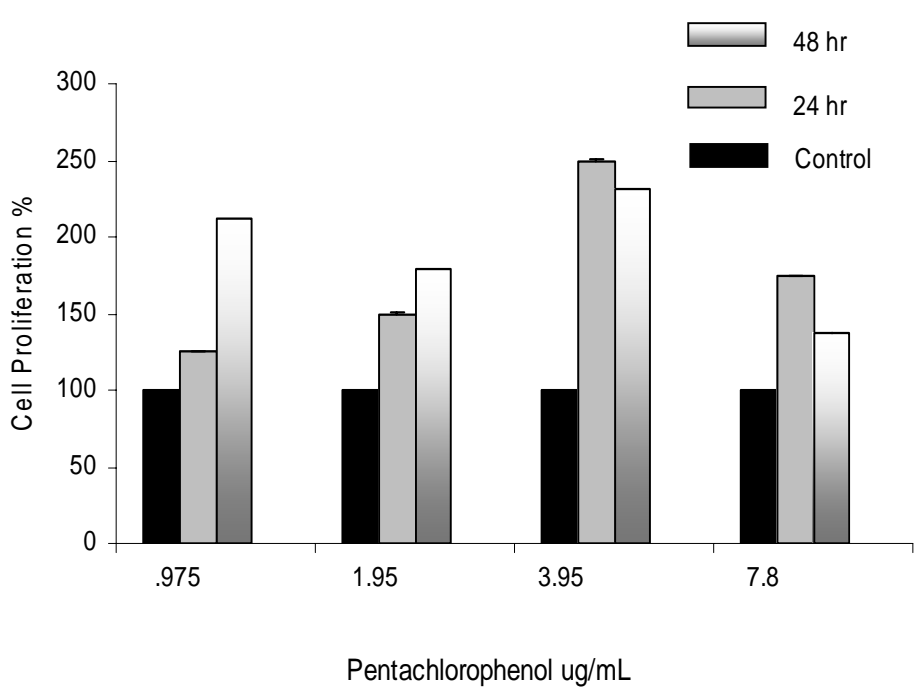

Figure 2. Mitogenic effect of pentachlorophenol on AML 12 mouse hepatocytes cells. AML 12 mouse hepatocytes were treated with sublethal concentrations of PCP (.975 $7.80 \mu \mathrm{g} / \mathrm{mL}$ ) for a $24 \mathrm{~h}$ and $48 \mathrm{~h}$ period. Cell proliferation was determined based on the MTT assay. Untreated hepatocytes were compared to PCP-treated hepatocytes to determine significant differences in stimulatory patterns. Bars are means \pm SDs, $\mathrm{n}=3$ with 8 replications per concentration. All values are significantly different from control $(0 \mu \mathrm{g} / \mathrm{mL} \mathrm{PCP}), p \leq 0.001$.

exposure, the percentages of cell proliferation of AML 12 mouse hepatocytes were about $100 \%, 125 \%, 150 \%$, $250 \%$, and $174 \%$ in $0, .975,1.95,3.95$, and $7.8 \mu \mathrm{g}$ $\mathrm{PCP} / \mathrm{mL}$, respectively. These results suggest that low doses of PCP are mitogenic in AML 12 mouse hepatocytes.

\section{Morphologic Changes in PCP-Treated AML 12 Mouse Hepatocytes}

We examined cell morphology with regard to duration and intensity of PCP-treated AML 12 mouse hepatocytes to determine cell injury. Morphologic changes in AML 12 mouse hepatocytes treated with PCP is shown in Figure 3. Morphologic injury was assessed by light-field microscopy and by determination of cell viability (MTT) post-exposure. PCP-treated hepatocytes (B), were distinguishable from that of untreated control (A). Upon $48 \mathrm{~h}$ of exposure, a $15.6 \mu \mathrm{g} \mathrm{PCP} / \mathrm{mL}$ concentration caused distortion of monolayer morphology, changes in cell shape, and decreased viability $(48 \pm 2.1 \%)$. We conclude that changes of cell morphology are closely related to the extent of stress and functional status of AML 12 mouse hepatocytes caused by PCP exposure.

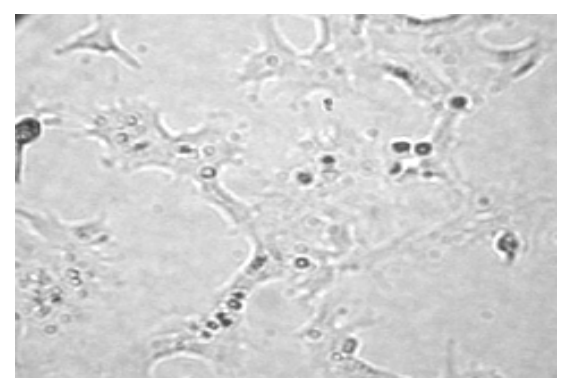

A: Untreated mouse hepatocytes used as control.

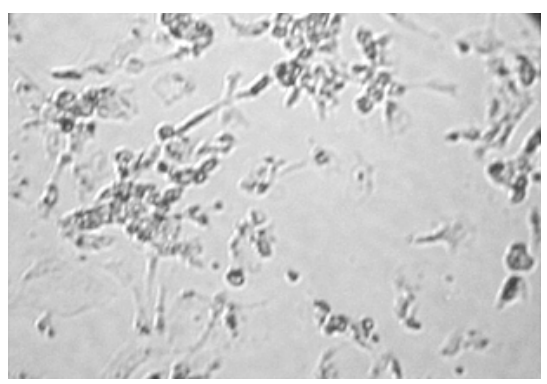

B: Morphologic changes in mouse hepatocytes at $15.6 \mu \mathrm{g} \mathrm{PCP} / \mathrm{mL}$, upon $48 \mathrm{~h}$ of exposure.

Figure 3. Morphologic changes in AML 12 mouse hepatocytes treated with pentachlorophenol.

\section{Discussion}

PCP-Induced Cytotoxic Effects in AML 12 Mouse Hepatocytes

Toxicity to mammalian cells is frequently an elaboration of dose-dependent occurrences as well as complex processes that respond to genotoxic stress. In the present study, we demonstrated that PCP $(100 \mu \mathrm{g} / \mathrm{mL}$ in $1 \% \mathrm{DMSO}$ ) is acutely toxic and causes injury to AML 12 mouse hepatocytes (Figure 1). This was evidenced by the ability of PCP to cause a $50 \%$ reduction in the viability of AML 12 mouse hepatocytes $\left(\mathrm{LC}_{50}=16.0 \pm\right.$ $2.0 \mu \mathrm{g} \mathrm{PCP} / \mathrm{mL})$. Interestingly, these results are consistent with previous findings from our laboratory that reported strong dose-response relationships with respect to the cytotoxic effects of PCP in $\mathrm{HepG}_{2}$ cells $(23.0 \pm 5.6 \mu \mathrm{g} \mathrm{PCP} / \mathrm{mL})$ and catfish hepatocytes $(1987 \pm$ $9.6 \mu \mathrm{g} \mathrm{PCP} / \mathrm{mL})[1,2,24]$. Although the mechanisms by which PCP exerts its toxic effect is somewhat unclear, we have demonstrated that the toxic potency of PCP is a dose-dependent event with regard to AML 12 mouse hepatocytes, $\mathrm{HepG}_{2}$, and catfish hepatocytes. 
Mitogenic Activity of PCP in AML 12 Mouse Hepatocytes

The mechanisms by which stress triggers signal transduction pathways that lead to mitogenic activity are of great interest. Steroid-like compounds, such as PCP, can influence rapid activation of cell proliferation and facilitate signal transduction through the G1 phase of the cell $[25,26]$. We previously reported that sublethal concentrations of PCP were mitogenic to $\mathrm{HepG}_{2}$ cells and catfish hepatocytes following 24- and $48 \mathrm{~h}$ of exposure $[1,2]$. In the present study, we demonstrated that low level concentrations of PCP were found to stimulate proliferative activity in AML 12 mouse hepatocytes (Figure 2). The greatest mitogenic response was observed at $3.95 \mu \mathrm{g} \mathrm{PCP} / \mathrm{mL}$.

Stress gene expression that facilitates cell proliferation, migration, differentiation, and survival, is the eventual outcome of signaling pathways that coordinate long-term cell adaptation. We have previously shown that $\mathrm{PCP}$ has the ability to transcriptionally activate the $c$-fos proto-oncogene, in $\mathrm{HepG}_{2}$ cells and catfish hepatocytes, [1,2,24]. c-fos has been implicated in proliferative machinery and is thought to be essential for mitogen-induced progression through the cell cycle [27]. Mitogen-activated protein kinase (MAPK) is one of the major signal transduction pathways activated when cells are exposed to inflammatory cytokines or stress [28]. Our findings strongly suggest that stress-activated protein kinases (SAPK)/Jun N-terminal kinases (JNK), members of the MAPK family, could be involved as a result of signal transduction within PCP-treated hepatocytes. Therefore, we believe that the SAPK/JNK cascade is likely to be involved in facilitating the mitogenic response in PCPtreated AML 12 mouse hepatocytes.

\section{Morphologic Changes in AML 12 Mouse Hepatocytes}

When cells are exposed to a variety of environmental stresses, cell death is the consequence of severely disturbed extracellular environmental conditions. However, if the injury is acute, the cell can survive in a damaged state and adapt to the injury (reversible) or it can die (irreversible or cell death) [29]. In the present study, morphologic changes in AML 12 mouse hepatocytes were the consequences of $48 \mathrm{~h}$ exposure to PCP (Figure 3). Severe changes in cell morphology were observed at $15.6 \mu \mathrm{g} \mathrm{PCP} / \mathrm{mL}$. We have shown that PCP causes injury to AML 12 mouse hepatocytes.

\section{Conclusions}

It can therefore be concluded from the findings of this research that: 1) PCP is acutely toxic to AML 12 mouse hepatocytes, with an $\mathrm{LC}_{50}$ of $16 \pm 2.0 \mu \mathrm{g} / \mathrm{mL}$ after 48 hours of exposure; 2) upon 24- and $48 \mathrm{~h}$ of exposure to sublethal concentrations, PCP demonstrated a strong mitogenic activity; 3) PCP causes injury to AML 12 mouse hepatocytes. This was confirmed by the morphologic changes in AML 12 mouse hepatocytes as a consequence of $48 \mathrm{~h}$ exposure; and 4) the toxic mechanisms of PCP are similar across cell lines.

Acknowledgments: This research was financially supported in part by a grant from the U. S. Department of Education through Title III Research Excellence Fund, Grambling State University, and in part by Title III Graduate Education Grant No. P031B990006-01 to Jackson State University. We thank Dr. Abdul Mohamed, Dean of the College of Science, Engineering and Technology, for his technical support of this research project.

\section{References:}

1. Dorsey, W. C.; Tchounwou, P. B.: CYP1A1, Hsp70, p53, and c-fos expression in human liver carcinoma cells $\left(\mathrm{HepG}_{2}\right)$ exposed to pentachlorophenol. Biomedical Research Instrumentation, 2003, 437, 389-396.

2. Dorsey, W. C; Tchounwou, P. B.: Pentachlorophenol - induced cytotoxic, mitogenic, and endocrine-disrupting activities in channel catfish, Ictalurus punctatus. International $J$. Environ. Research and Public Health. 2004, 2, 7483.

3. Fisher, B.: Pentachlorophenol: toxicology and environmental fate. J. Pesticide Reform. 1991, 11(1), 1-5.

4. Kavlock, R.; Ankley, G.; Francis, E.: Grag, E.; McMaster, S.; Reese, D.; Sayles, G.; Sergeant, A.; Vallero, D.: Research plan for endocrine disruptors: a report of the U.S. EPA. EPA600R98087. 1998.

5. Patino, R.; Maule, A. G.: Estrogen receptors in leukocytes from immature channel catfish. Dev. Comp. Immunol. 1997, 2, 123-24.

6. Colborn T.; vom Saal F. S.; Soto, A. M.: Developmental effects of endocrine-disrupting chemicals in wildlife and humans. Environ. Health Perspectives. 1993, 101(5), 256-257.

7. Meacher, M.: Speech to SERA Conference. $25^{\text {th }}$ January 1997.

8. De Solla, S. R.; Bishop, C. A.; Van Der Kraak, G.; Brooks, R. J.: Impact of organochlorine contamination on levels of sex hormones and external morphology of common snapping turtles (Chelydtra serpentina serpentina) in Ontario, Canada. Environ. Health Perspectives. 1998, 106, 253-260.

9. U. S. Environmental Protection Agency. Treatment technology performance and cost data for remediation of wood preserving sites. Office of Research and Development, Washington, D.C. EPA625R97007, 1997.

10. National Toxicology Program: NTP toxicology and carcinogenesis studies of penta- chlorophenol (CAS 
No. 87-86-5) in F344/N Rats (Feed Studies). Natl Toxicol Program Tech. Rep. Ser., 1999, 483, 1-182.

11. U. S. Environmental Protection Agency: Pentachlorophenol (non wood uses) special review position document 2/3. Washington, D.C. Office of Pesticides and Toxic Substances. 1984. pp 15-16.

12. Agency for Toxic Substances and Disease Registry: ToxFAQs(tm) for Pentachloro-phenol CAS No. 8786-5. URL: www.astr.cdc.gov/tfacts51.html, 2001.

13. Daniel, V.; Wolfgang, H.; Klausdieter, B.; Opelz, G.: Impaired in-vitro lymphocyte responses in patients with elevated pentachlorophenol (PCP) blood levels. Archives of Environmental Health. 1995, 50, 287-292.

14. Rugman, F. P.; Cosstick, R.: Aplastic anemia associated with organochlorine pesticide: case reports and review of evidence. J. Clinical Pathology, 2000, 43, 98-101.

15. Winsholz, M.: The Merck Index. $10^{\text {th }}$ ed. Rahway, NJ: Merck and Co., 1983. p.1021.

16. Wagner, S. L.: Clinical Toxicology of Agricultural Chemicals. Oregon State University Environmental Health Sciences Center, Corvallis, OR. 1981.

17. Agency for Toxic Substances and Disease Registry (ATSDR): Toxicological Profile for Pentachlorophenol (Draft). U.S. Public Health Service, U.S. Department of Health and Human Services, Atlanta, GA. 1992.

18. Spalding, J. W.; French, J. E.; Stasiewicz, S.; Furedi-Machacek, M.; Conner, F.; Tice, R. R.; Tennant, R. W.: Responses of transgenic mouse lines p53 (+/-) and Tg.AC to agents tested in conventional carcinogenicity bioassays. Toxicol. Sci., 2000, 53, 213-223.

19. Chhabra, R. S.; Maronpot, R. M.; Bucher, J. R.; Haseman, J. K.; Toft, J. D.; Hejtmancik M. R.: Toxicology and carcinogenesis studies of pentachlorophenol in rats. Toxicol. Sci. 1999, 48, 14-20.

20. U.S. Environmental Protection Agency: Integrated Risk Information System (IRIS) on Pentachlorophenol. Environmental Criteria and Assessment Office, Office of Health and Environmental Assessment, Office of Research and
Development, Cincinnati, OH. 1993.

21. Pope, A.; Rall, D.: Environmental medicine: integrating a missing element into medical education. Committee on Curriculum Development in Environmental Medicine. Institute of Medicine. National Academy Press, 1995, pp 542-555.

22. Colosio, C.; Maroni, M.; Barcellini, W.; Meroni, P.; Alcini, D., Colombi, A. D.; Foa, V.: Toxicological and immune findings in workers exposed to pentachlorophenol (PCP). Archives of Environ. Health, 1993, 48(2), 81-88.

23. Wood, S.; Rom, V. N.; White, G. L.; Logan, D. C.: Pentachlorophenol poisoning. J. Occupational Medicine, 1983, 25, 527-30.

24. Dorsey, W. C.; Tchounwou, P. B.; Ishaque, A. B.; Shen, E.: Transcriptional activation of stress genes and cytotoxicity in human liver carcinoma $\left(\mathrm{HepG}_{2}\right)$ exposed to pentachlorophenol. International $J$. Molecular Sci., 2002, 3, 989-1004.

25. Burow, M. E.; Yang, T.; Collins-Burow, B. M.; Krajewski, S.; Reed, J. C.; McLachlan, J. A.; Beckman, B. S.: Effects of environmental estrogens on tumor necrosis factor $\alpha$-mediated apoptosis in MC7-cells. Carcinogenesis. 1999, 20(11), 20572061.

26. Marino, M.; Acconcia, F.; Bresciana, R.; Weiz, A.; Trentalance, A.: Distinct non- genomic signal transduction pathways controlled by $17^{\beta}$-estradiol regulate DNA synthesis and cyclin $D_{1}$ gene transcription in $\mathrm{HepG}_{2}$ cells. Molecular Biology of the Cell, 2002, 13, 3720-3729.

27. Sasaki, Y.; Sugamura, K.: Involvement of Hgs/Hrs in signaling for cytokine-c-fos induction through interaction with TAK1 and Pak1. J. Bio. Chem., 2001, 276, 2999433-29952.

28. Derijard, B.; Hibi, M.; Wu, I. -H.; Barrett, T.; Su, B.; Deng, T.; Karin, M.; Davis, R. J.: JNK1: a protein kinase stimulated by UV light and Ha-Ras that binds and phosphorylates the c-Jun activation domain. Cell, 1994, 76, 1025-1037.

29. Firpo, A.: Cell injury. Cornell University Medical College Education Center. URL: http://edcenter.med.cornell.edu/CUMC_PathNotes/ $\underline{\text { Cell.Injury/Cell_Injury.html }}$ 